\title{
Transformation of Traditional Food with Duck Basic for Culinary Business Continuity in Ubud Tourist Village, Gianyar, Bali, Indonesia
}

\author{
I Nyoman Tri Sutaguna \\ Management Tourism of Universitas Udayana, Bali, Indonesia \\ Email trisutaguna@unud.ac.id \\ I Ketut Sirna \\ Management Study Program of Universitas Dhyana Pura, Bali, Indonesia \\ Email sirna@undhirabali.ac.id
}

I Gusti Bagus Rai Utama

Hospitality Management Study Program of Universitas Dhyana Pura, Bali. Indonesia

Email raiutama@undhirabali.ac.id

\begin{abstract}
Ubud Village, which is one of the attractions for tourists to visit the island of Bali, has a very beautiful and beautiful view. Tourists who visit Ubud not only enjoy the physical views of natural and man-made resources but they also want to learn about the original Balinese culture that breathes Hinduism. One thing that tourists can learn from Balinese culture is enjoying traditional Balinese food (culinary tours). This study aims to identify traditional Balinese food made from duck meat in terms of (1) The transformation product of traditional Balinese food made from duck and (2) Food contained in traditional Balinese food. The informants were determined by selecting restaurants and restaurants that sell traditional Balinese food which had been transformed and determined based on the purposive sampling method. Determination of information from tourists used in-depth interviews with resource persons who are competent in their fields. Data collection techniques are using observation, interviews, and documentation. The presentation of the research results is described quantitatively and qualitatively. Transformation processes such as texture, shape, taste, color, the aroma of the processing process, and attractive presentation methods, taking into account sanitary, hygienic, and food safety standards. Furthermore, the meaning of the transformation of traditional Balinese food made from a duck that has been developed is in the form of economic meaning, social meaning, ethical meaning, and aesthetic meaning. This will be able to provide added value to tourists and the community in Ubud Tourism Village.
\end{abstract}

Keywords: Transformation, Balinese Traditional Food, Ubud Tourism Village.

\section{Introduction}

Bali as a destination has a variety of cultures and arts, both in the fields of dance, music, painting, sculpture, and food processing which is often called culinary arts. Besides, the island of Bali has a very well-known culture such as arts, religious rituals, and culinary preparations that can arouse the appetite of tourists who come to Bali. The culinary art or the art of processing food and beverages has been famous since ancient times (Suriani, 2009).

For this reason, hard efforts are needed so that Balinese food has value in the eyes of visiting tourists so that authentic Balinese food will become a basic requirement of tourists visiting Bali. According to Suci (1986) in Suriani (2009), that Bali still has regional specialties, especially 
aspects of processing and presentation that need to be developed to attract tourists who want to enjoy things that cannot be experienced in everyday life.

In general, Balinese food sold in hotels or restaurants sells more continental food as the main menu. The reason is that many tourists want to get food that is modern and comes from abroad or European food. This is certainly very sad because selling authentic Balinese food products will increase tourism promotion and the economy of the local community. This will have a positive impact on tourism in Bali in particular and Indonesia in general.

There are many ways to make Balinese food of good quality, not only for domestic tourists but also for foreign tourists. Several techniques can be applied either by changing processing techniques, mixing spices and ingredients as well as the way they are served. The food you enjoy not only has a good taste but in terms of appearance when served, it also provides added value that is attractive to tourists. There are several ways to further improve the quality of food produced, namely by paying attention to good sanitation, hygiene, and safety standards for food processing. This will attract tourists, both domestic and foreign tourists who enjoy Balinese food with satisfaction and safety. For this reason, what needs to be considered is the maximum effort and good cooperation between the components involved in the processing of traditional Balinese food. This is necessary so that Balinese specialties can be famous throughout the world and have a good international standard with the characteristics of the ancestral heritage of the Balinese people.

The more various types of food that are served to consumers in the Ubud area, it will become a special attraction for tourists who want to vacation in that place. One type of Balinese food that is very famous in Bali is betutu chicken or pork roll. This food has a soft meat taste with delicious, savory, and spicy Balinese spices. In its presentation to consumers or tourists, chicken betutu has a transformation in terms of shape, texture, color, taste, aroma, seasoning, processing, or the way it is served which will be adjusted to the quality and market demand (Utama, et al., 2020).

Many of the entrepreneurs (stakeholders) find this opportunity to be a promising business land so that in the Ubud area not only sells handicrafts, art goods but also sells products from traditional Balinese culinary arts. With the capital of knowledge, experience, disciplines obtained in the industry, and sufficient capital, these entrepreneurs are involved in a business that is engaged in traditional Balinese food products.

The research formulation is consist of 1) What products from the transformation of traditional Balinese food products in Ubud, and 2) What meanings are contained in the transformation of these foods, it will be interesting to study and research as an object. Therefore, this research is expected to produce a study that shows that the transformation process of traditional Balinese food, especially those that use basic ingredients from duck with various spices, is the basis of ingredients that will support the tourism industry in Bali in general and Ubud in particular. The reason is that the duck-based food menu is very popular with tourists and needs to be transformed to attract more tourists to buy it.

\section{Research Methods}

This research is located in the Tourism Village of Ubud, Gianyar Regency. The reason for choosing this location is because Ubud Tourism Village is a famous tourist destination and there are many restaurants in the area that sell traditional Balinese food, especially those made from duck.

Types of data in this study consisted of qualitative data, namely interview data obtained from informants. Meanwhile, quantitative data is data in the form of written information in the form of numbers such as the number of informants (Utama and Mahadewi, 2012).

Sources of data in this study using primary data sources, namely from informants and observed tourist objects. This is in the form of activities carried out by tourism actors. Meanwhile, the secondary data sources used are literature/references and other documents. 
The informants were determined by selecting restaurants and restaurants that sell traditional Balinese food which had been transformed and determined based on the purposive sampling method. This means that the selection of restaurants that are deemed appropriate to the research topic is based on certain knowledge and considerations from research, for example, the willingness of time and energy including the ease of obtaining data, based on these provisions there are 4 transformed restaurants and restaurants that provide traditional Balinese food (Utama, 2016).

The data collection technique in this research is by using observation, interview, and documentation techniques. In data collection techniques carried out in qualitative research is a recording technique using a camera to take pictures or photos. All data is obtained by recording all activities carried out by tourism actors in Ubud Tourism Village, for example in preparing raw materials, preparing ingredients until they are ready to be cooked, processing ingredients until they are ready to be served, and enjoyed (Utama, 2015).

This research uses qualitative descriptive analysis techniques, namely, analysis based on the data collected, then described with sentences based on theoretical foundations so that clear sentences will be formed and can answer the objectives of this study. For the results of data analysis, a formal presentation will be presented, namely, the presentation of the results of the study in the form of photographs and informally in the form of narrative text which contains a brief description so that it is easier to understand what is happening according to what is found and understood in the field (Utama and Mahadewi, 2012).

\section{Results and Discussion}

\subsection{Products of the transformation of traditional Balinese food made from duck served by restaurants to tourists in Ubud}

Based on the results of observations and interviews conducted on the managers of restaurants and restaurants in Ubud, and the steps taken in transforming traditional duck food products are as follows.

\subsubsection{Recipe for Making Food Ingredients}

Food ingredients are formulated in such a way that cannot be separated from cooking, where the spices will give taste to the food we are serving. Duck is originally a traditional Balinese food and in its development to meet the needs of tourists, who come to Ubud Village, undergo a transformation process including the spices used. The spice transformations carried out are as follows:
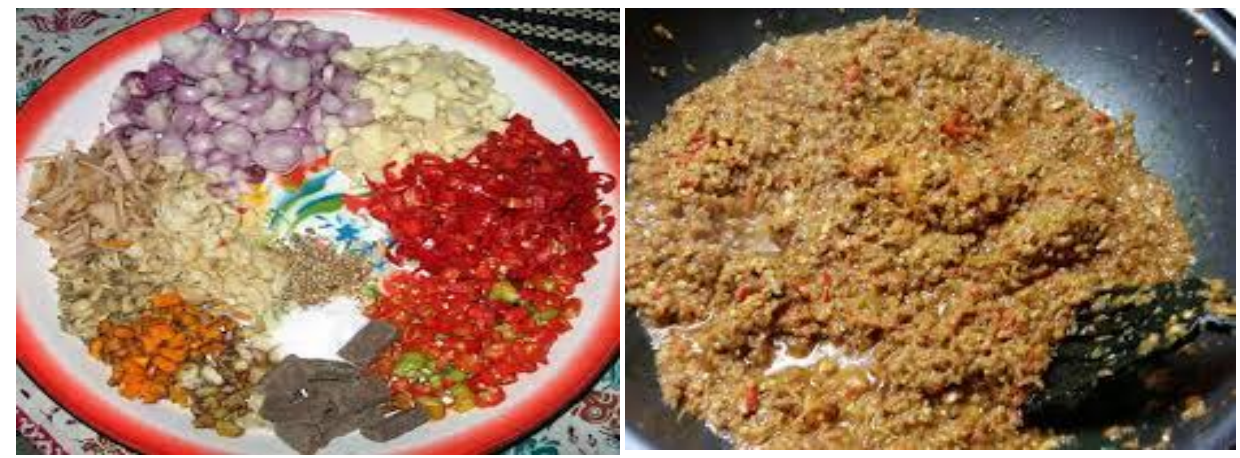

Figure 1 Basic Seasoning and Traditional Betutu Duck Crabs

Meanwhile, the ingredients for making a duck Betutu transformation can be seen in Figure 2 below. 


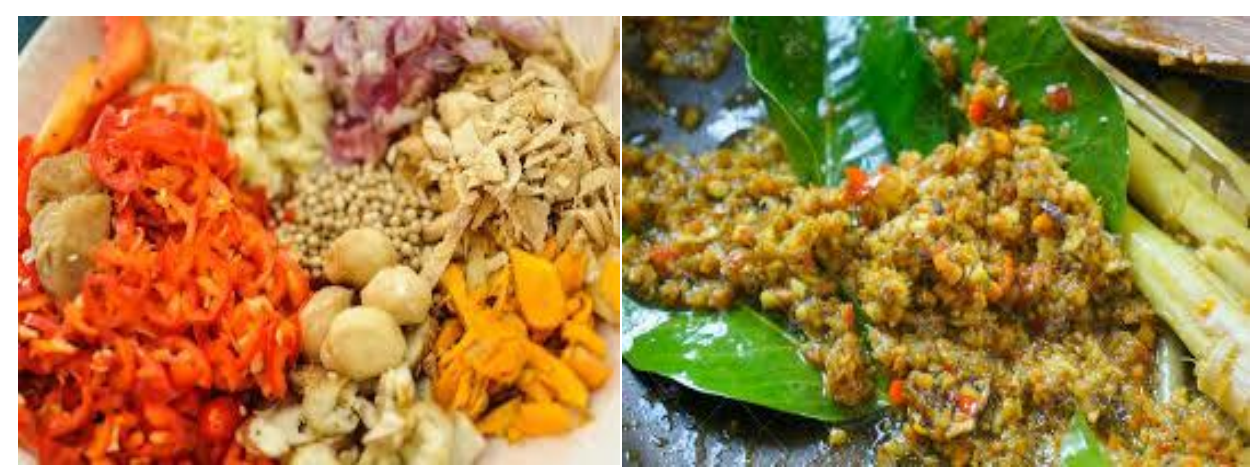

Figure 2 Basic spices and results of the Transformation of Betutu Duck

\subsubsection{Food Processing Techniques}

Before the dish is served, the food ingredients will undergo processing first, the food processing served by a restaurant or restaurant that serves traditional duck-based food has undergone several changes. This can be seen, for example, ducks require a cooking process for 4 hours, but with the development of cooking equipment this process can be minimized to 2 hours. Where one of them is in the process of boiling duck meat using a pressure cooker with high pressure so that the meat to be processed will be tender (cooked) faster. The following are the stages in the process of making various types of ducks, both traditional and transformed types.

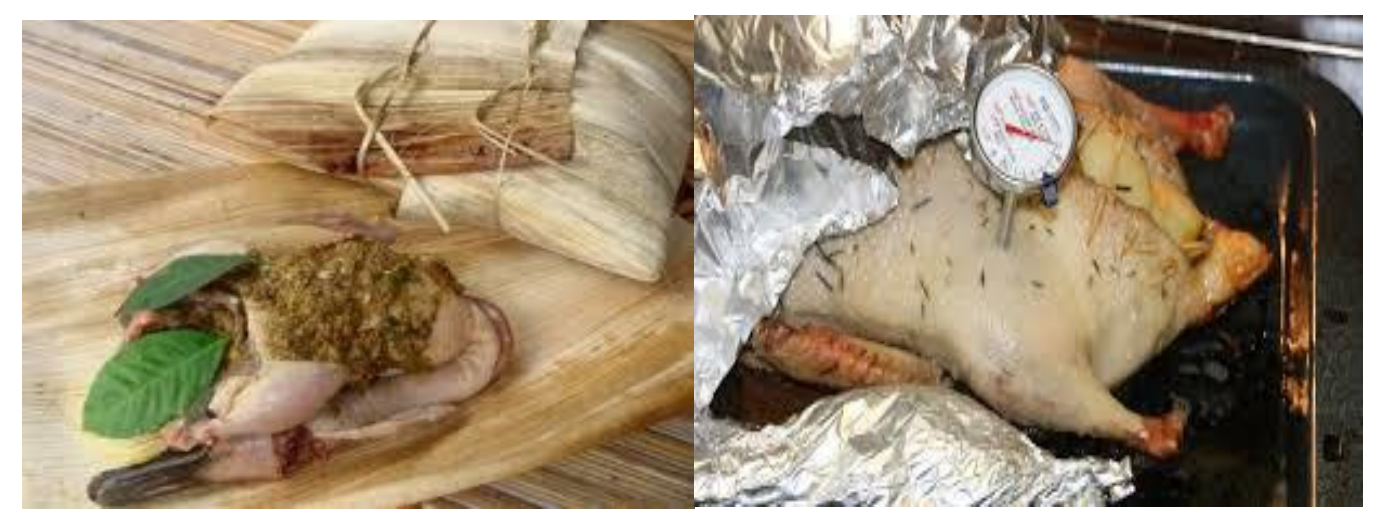

Figure 3 Traditional Betutu Duck Processing Method and Transformation Betutu Duck

\subsubsection{Quality of Food Aroma and Taste}

Tourists visiting the tourist area of Ubud will enjoy a culinary tour in Ubud village. One of the famous culinary from Ubud village is a duck. Before being transformed, this food has a simple presentation and tends to be spicy. From the results of observations and interviews with several tourists, foreign tourists say that the food they usually eat is soft and not spicy. Meanwhile, domestic tourists say that the food they eat usually tends to be sweet. Especially domestic tourists from Java and other domestic tourists who like it not spicy especially for young people.

To meet the diverse tastes of tourists, the manager of a restaurant or restaurant in Ubud Village carries out several taste transformations in traditional duck-based food, such as duck in traditional food which is usually served spicy to meet the tastes of tourists. existing in Ubud Village has undergone a change and has been adjusted to the desires of consumers to be not spicy, and the taste is slightly sweet, by reducing the use of chilies to reduce the spicy taste and by adding sugar, 
especially Balinese sugar which will give a distinctive feature to the food we will serve. To get a good taste, slightly sweet, food ingredients and seasonings are also very concerned. This can be seen in Figure 4 where the spices used are very concerned about the quality and in the process of making the spices.

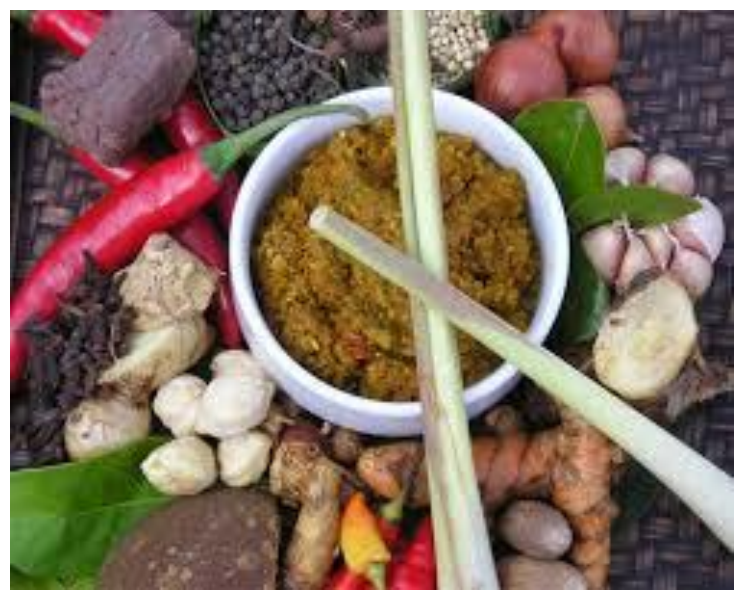

Figure 4 Quality of Traditional Balinese Food Seasoning

After the spices have been sorted by choosing spices for consumption and the spices are then cleaned.

\subsubsection{Food Arrangement and Serving}

Food presentation is traditionally used as a reference in determining the pattern of serving and serving dishes used in restaurants or restaurants in Ubud, considering that every tourist has a different eating culture in a restaurant or restaurant, the restaurant or restaurant in Ubud Village still highlights serving food with Balinese nuances, namely by transforming the way of serving Rsi Bujana and Megibung. The presentation of traditional food in the past without paying attention to appearance, food is served by simply mixing it on a plate to attract consumers, restaurants or restaurants in Ubud Village are very concerned about serving food menus served to consumers by complying with sanitary standards, hygiene, and food safety (Utama, 2015). This can be seen in the comparison between traditional food that was served just like that as shown in Figure 5.

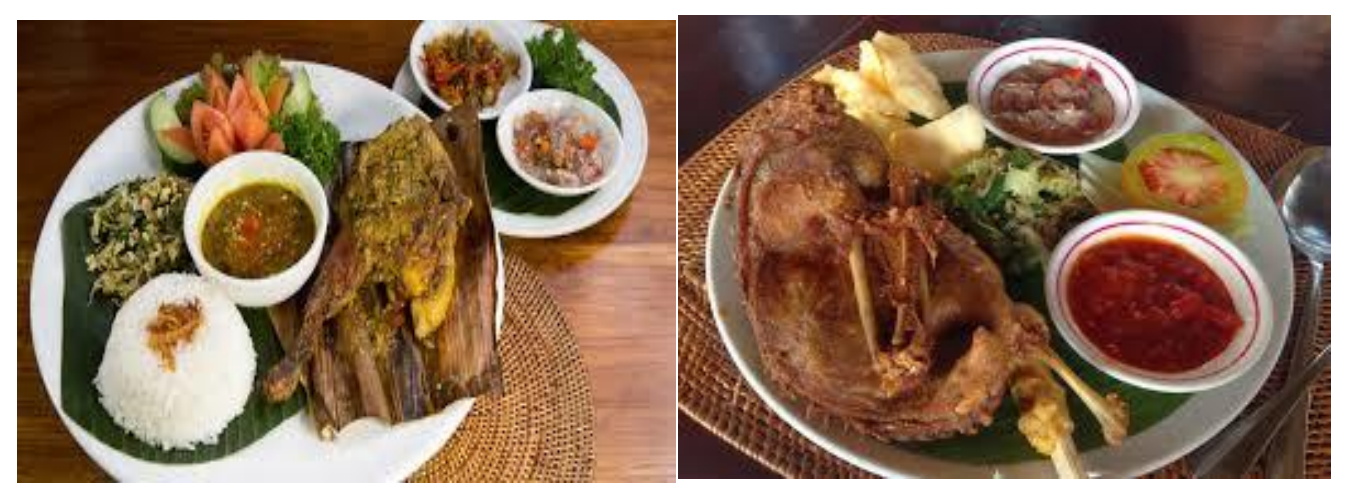

Figure 5 Arrangements and Presentation of Traditional Betutu Duck and Transformed Bebek Betutu 


\subsection{The Meaning of Transformation of Duck-Based Balinese Traditional Food in Ubud Tourism Village.}

\subsubsection{Economic Meaning}

Tourism can develop in an area if tourism activities can have a positive impact on the local economy (Pitana and Gayatri, 2005). In discussing the economic meaning obtained from gastronomy in the Ulihan tradition, it cannot be separated from the commodification process. The word commodification describes the economic value of something that previously had no value from an economic point of view. It is sometimes used to describe a market transformation for a unique, branded product based on an undifferentiated product. It is further added by Lee (2006), that the commodification of products is the fact that they are first produced to be exchanged for profit. Commodification has a broad meaning and does not only concern the issue of commodity production of goods and services being traded. The problem is how these goods and services are distributed and consumed is also included in it. Economic meaning is obtained by packaging material preparation activities, processing food ingredients into food that is ready to be enjoyed and presenting it or packaging it into an interesting story and activity and allowing tourists to participate in this material preparation activity so that it becomes something to see (something to see), done (something to do), and bought (something to buy) which is a requirement for a tourist attraction (Utama, 2016).

\subsubsection{Social Meaning}

Tourism is an activity that directly touches and engages the community (Pitana and Gayatri, 2005). Community involvement in tourism activities can be in the form of providing tourism facilities or as workers in their fields related to tourism facilities such as tour guides, hotel employees, villas and restaurants, and other types of services. In connection with the economic meaning obtained in the form of an economic increase from this community involvement, automatically their social degree will increase. This change in social status affects the social order, where all members of society are required to be the same regardless of lineage, caste, and so on.

From the tourist point of view, the social meaning obtained is in the form of a means to increase social status or status as well as a means of social interaction to be able to carry out social interactions with peers or with local communities visited. As stated by Ryan, 1991 (in Pitana and Gayatri, 2005) tourists choose certain tourist destinations to meet their needs and wants. The biological need for food and drink, especially food and drinks that have never been enjoyed in the tourist's home country, can be a matter of pride that can be shared with colleagues, neighbors, and relatives as a means of increasing social status in the tourist's home environment (Utama, 2016).

So the social meaning obtained from the transformation of traditional Balinese food in Ubud Tourism Village from an inter-community perspective can be in the form of linkages between community members, social institutions, and the rhythm of social life.

\subsubsection{Ethical and Aesthetic}

Meanings As stated by Gisslen (2004), a dish/food is like a painting and the plate on which to serve it in the frame. However, this does not mean that it takes a lot of time in arranging food on a plate as a painter makes his works, because this can be a bad thing if food has to be served fresh. In presenting food, the following should be considered, namely; Balance (balance between plate size, main course, sauce, and complementary / garnish), Colors (more than one color between main food, atmosphere, and accompaniment/decoration so it doesn't look monotonous), Shapes (a form of food that consists of several more types interesting as well as the color), Texture (although the texture of the food is not clearly visible and can only be proven by touch, it is also very important to 
pay attention not to serve foods that are all soft textured), Flavor (the aroma of food that varies in one plate will make food more interesting).

The development of rural tourism certainly affects the physical, social, and cultural environment of the local community. The meaning of ethics and aesthetics in the context of environmental preservation is in the form of increasing public awareness to maintain their assets in the sense that they are not tempted to sell land to investors who want to build tourism facilities in Ubud Tourism Village (Utama, et al., 2020).

\section{Conclusions and Suggestions 4.1 Conclusion Based}

On the descriptions in the previous chapters, the following conclusions can be drawn:

1. The transformation product of traditional Balinese food that is served is a traditional food made from duck and has been transformed and has undergone several modification processes such as:

a) The seasonings, in the form of several ingredients that are used only in traditional betutu ducks such as jejaton, are not used in transformed betutu ducks.

b) The processing process has undergone a change from being directly covered, which takes 812 hours to make a traditional betutu duck, while in the making of a duck betutu there are changes such as the addition of aluminum foil to the final wrapping or some boiling or steaming before the oven is needed time $2-3$ hours.

c) The taste, in the process of transforming the traditional duck betutu which is usually served spicy, is transformed into the duck betutu which tastes soft, savory, crunchy, and sweet.

d) Presentation, transforming the way of serving traditional Betutu duck food into transforming duck betutu is by combining traditional methods, namely Rsi Buajana and Megibung which in theory are closer to the Rijstafel Service combined with the America Service.

2. The meaning of transformation of traditional Balinese food in Ubud Tourism Village is the economic meaning in the form of added value from commercializing the transformation of traditional Balinese food made from duck, the social meaning in the form of social interaction and job opportunities for the community as well as the ethical and aesthetic meaning of beauty. the beauty and ecological balance of Ubud Tourism Village.

\subsection{Suggestions}

Based on the results of the research outlined in the above conclusions, several suggestions can be put forward so that the transformation of traditional Balinese food made from a duck in Ubud Tourism Village can be used as a tourist attraction as follows:

a) The products of the transformation of traditional Balinese food made from a duck in Ubud Tourism Village to be developed according to the principles of modern gastronomy but still retain their originality, authenticity, and uniqueness so that they have uniqueness as a tourist attraction.

b) To give a broader meaning of gastronomic development to culinary transformation in Ubud Tourism Village, especially for tourists and local communities, the involvement of mothers who are accommodated in a PKK organization forum and the younger generation who are members of the youth organization and sekehe teruna teruni can be improved.

c) Given the limitations of this study seen from the perspective of commercial or marketing aspects, tourism planning, and management of Ubud Tourism Village with its gastronomic appeal, this research is continued by other researchers so that research in the gastronomic field can be of benefit to the parties concerned. 


\section{References}

[1] Kartasasmita, Ginanjar. 1997. Community Empowerment: A Development Concept Rooted in Society. The material at the Golkar Tk.I East Java DPD Workshop on March 14, 1997.

[2] Nikijuluw, Viktor P.H. 2001. Population and Socio-Economy of Coastal Communities and Their Empowerment Strategies in the Context of Integrated Coastal Resource Management. Papers on Integrated Coastal Management Training. Coastal Project, Center for Coastal and Ocean Resources Studies, Bogor Agricultural University (IPB).

[3] Payne M. 1997. Modern Social Work Theory. Second Edition. London: MacMillan Press Ltd.

[4] Picard, Michel. 2006. Bali: Cultural Tourism and Cultural Tourism. Jakarta. KPG (Popular Gramedia Library) Jakarta -Paris Forum.

[5] Rukendi, Cecep, and Baskoro, Bra. 2010. Asset-Based Tourism Development in the Context of Combating Poverty in Indonesia, in Hermantoro,

[6] Hengky, et al. 2010. Tourism Eliminating Poverty. Center for Tourism Research and Development. Jakarta.

[7] Silalahi, Ulber. 2009. Social Research Methods, Bandung. Refika Aditama.

[8] Slamet, M. 2003. Community Empowerment. In Forming Patterns of Human Development Behavior. Edited by Ida Yustina and Adjat Sudradjat. Bogor: IPB Press.

[9] Sofield, T.H.B. 2003. Empowerment for Sustainable Tourism Development. Social Tourism Science Series, UK: Elsevier Science Ltd., Pergamon.

[10] Sumardjo. 1999. "Transformation of Agricultural Extension Model Towards Development of Farmer Independence: A Case in West Java Province". Doctoral Dissertation. Bogor: Graduate Program, Bogor Agricultural University

[11] Utama, I.G.B.R. and Junaedi, I.W.R., 2019. Program Kemitraan Masyarakat Desa Wisata Blimbingsari, Melaya, Jembrana, Bali. Paradharma (Jurnal Aplikasi IPTEK), 2(2).

[12] Utama, I.G.B.R. and Junaedi, W.R., 2019, October. PROGRAM KEMITRAAN MASYARAKAT DESA WISATA WARISAN BUDAYA JATILUWIH, TABANAN, BALI. In Seminar Nasional Aplikasi Iptek (SINAPTEK).

[13] Utama, I.G.B.R. 2016. Pemasaran Pariwisata. Yogyakarta: Andi

[14] Utama, I.G.B.R. 2015. Pengantar Industri Pariwisata. Yogyakarta: Deepublish

[15] Utama, I.G.B.R., Mahadewi, N.M.E 2012. Metodologi Penelitian Pariwisata dan Perhotelan. Yogyakarta: Andi

[16] Utama, I.G.B.R. 2016. Metodologi Penelitian Pariwisata dan Hospitalitas. Denpasar: Pustaka Larasan.

[17] Utama, I. G. B. R., Turker, S. B., Widyastuti, N. K., Suyasa, N. L. C. P. S., \& Waruwu, D. (2020). Model of Quality Balance Development of Bali Tourism Destination. Technium Social Sciences Journal, 10(1), 455-464. https://doi.org/10.47577/tssj.v10i1.1356

[18] Utama, I. G. B. R., Junaedi, I. W. R., Krismawintari, N. P. D., Pramono, J., \& Laba, I. N. (2020). New Normal Acceleration Strategy for Bali Tourism Destination Recovery with E-Tourism and Special Health Protocol for the Tourism Sector. Technium Social Sciences Journal, 10(1), 156-166. https://doi.org/10.47577/tssj.v10i1.1332 